\title{
Immunoexpression of cytokeratin 19 in oral cavity mucous smear of filter cigarette smokers
}

\author{
Isra Meira, Sunardhi Widyaputra, Murnisari Dardjan \\ Department of Oral Biology Faculty of Dentistry Universitas Padjadjaran
}

\section{ABSTRACT}

Smoking has become general habits in social life. One popular kind is filter cigarette. As base component is tobacco without clove and separated by filter on it. Long irritation from heat and toxic component of cigarette changed in oral mucosa epithelial. This condition can stimulate the increase of progenitor cells, which is marked by immnuhistochemistry staining method of cytokeratin 19. This descriptive study is to find the expression of cytokeratin 19 in oral mucosa cytoplasm epithelial of filter cigarette smokers. There were 30 smokers which were selected with certain criteria. Samples were taken from cytological smear of mucosa epithelial then stained with immunohistochemistry method. Analysis has taken by calculating the number of cells in cytological smear. Then the immunoexpression of cytokeratin 19 was known from the percentage of cytoplasm cells which have brown color compared with total number of cells. In conclusion, the smoking filter cigarette would increase the number of progenitor cells from chronic inflammation, which is marked by cytokeratin 19 expression in oral mucosa cytoplasm epithelial of smokers.

Key words: Cytokeratin 19, filter cigarette smokers, immunohistochemistry

\section{INTRODUCTION}

Smoking habit is considered as a very common and widespread habit in the society. In modern countries, the smoking habit tends to decrease while in the third world countries this habit seems to increase. According to some research, there is a tendency of increasing number of smokers in Indonesia, especially among adolescents. ${ }^{1}$

Asmoker finds it difficult to stop smoking. This is due to the nicotine content inside the cigarette smoke. Nicotine has some pharmacological effects that encourage habituation factor or psychological dependency. ${ }^{2}$ Besides nicotine, smoke from a cigarette also contains tar that can be accumulated on dental surfaces and dental root that makes the surface rough and makes plaque attachment easier. A good filter should, off course, be able to reduce the content of a cigarette bar. ${ }^{2}$ The use of filter in a cigarette may also reduce the quantity of tar and nicotine. ${ }^{3}$

Smoking has been known since a long time ago as having relation with various chronic diseases such as lung diseases and cardiovascular diseases. In addition, the systemic impact of smoking habit in the form of oral manifestation is also frequently found. ${ }^{4}$ Oral cavity receives the most severe cigarette smoke at the time when the tobacco is burnt in the form of toxic substances and irritating heat. Chronic irritation caused by cigarette smoke 
and plaque and calculus deposits and poor oral hygiene can cause various inflammation and damages in oral mucous including hypertrophy, hyperplasia, total thickening of ephitelials known as Smoker's Keratosis and white lesions in the form of leucoplakia and oral cancer. ${ }^{5}$

There are several types of keratin cell in the oral cavity and other parts of body that is known as cytokeratin. One of the cytokeratins that can be used as a marker to show the cell's condition is cytokeratin 19 which is the lightest cytokeratin in human body. This cytokeratin is found in a high numbers in the epithelial cells including the epithelial of glands. ${ }^{6}$

Basal keratinocyte is a progenitor cell that plays a role in oral epithelial cell renewal process. An increased progenitor cell number may happen in a chronic inflammation caused by various factors including bacteria, virus, parasite infection, chemical irritants, and non digestible particles. ${ }^{7}$ The presence of this progenitor cell can be detected by cytokeratin 19 that is smeared immunohistochemically. Immunohistochemistry is a staining using antibody to localize a specific cell and tissue, which is the most sensitive and specific technic in histochemistry. ${ }^{8}$

Based on those facts, the author is interested to do a study to observe the presence of the progenitor cell in the oral cavity mucous smear preparation, especially in samples from filter cigarette smokers after a certain time period.

\section{MATERIALS AND METHODS}

The type of the study performed is a descriptive study. This study was performed by using buccal, labial and palatal mucous cytological swabbing from oral cavity. The study population consists of 30 Universitas Padjadjaran students who have a habit of smoking filter cigarette. The sampling was performed using purposive sampling technique, i.e. selection of a subject group based on certain considerations and criteria.

The criteria for the population are: Male, 18-25 years old; Good general health, no systemic disorders; Has been smoking filter cigarette for $\geq 1$ year; Smoke 5-10 filter cigarettes or more in one day; Does not consumed illicit drugs such as narcotics, psychotropic drugs and other addictive substances; Does not consume alcohol; Does not wear prothesis or removable or fixed orthodontic device; Does not have oral habit, such as lip or cheek biting; Does not suffer from cancer or follow radiation therapy; At the time of taking oral swab and examination, subject is not chewing hard candy or similar candies and did not chew it before sampling; and want to join the study as subject. Before oral swab was performed to get cytologic sample, an interview was done to fill out a form and to get informed consent.

Positive control: The positive control was taken from tongue carcinoma paraffin block preparation that will give positive staining result using cytokeratin 19. Negative Control: The negative control was taken from one of patients whose swab was done twice without applying cytokeratin 19 antibody.

\section{Smear assessment}

The oral cavity smear result assessment using immunohistochemical staining to detect cell changes is interpreted by these results: the cytokeratin 19 smear is considered positive if there is a brown color in the cell cytoplasm. The cytokeratin 19 smear is considered negative if there is no brown color in the cell cytoplasm.

\section{RESULTS}

From the observation of 30 oral mucous smear preparation from filter cigarette smokers, a following data is gained: 4 smear preparations with negative smear results and 26 smear preparations with positive smear results. Therefore, a percentage of $13.33 \%$ for negative preparation and $86.67 \%$ for positive preparation are gained.

There are 121,993 cells of total cells in 30 smear preparations. Meanwhile the number of cells that are smeared by cytokeratin 19 or those that show positive result is 8,408 cells. Therefore, it is revealed that the average percentage for comparison between the number of total positive cell and the total number of cell collected from 30 cigarette smoker oral mucous smear preparations is $6.89 \%$.

\section{DISCUSSION}

Some positive results show that cells in oral mucous epithelial has undergone changes that 
Table 1. Results of cytokeratin 19 smear on oral mucous smear preparation from subjects.

\begin{tabular}{cccc}
\hline $\begin{array}{c}\text { No. } \\
\text { Sample }\end{array}$ & $\begin{array}{c}\text { Result } \\
\text { preparation }\end{array}$ & $\begin{array}{c}\text { No } \\
\text { Sample }\end{array}$ & $\begin{array}{c}\text { Result } \\
\text { preparation }\end{array}$ \\
\hline 1 & + & 16 & + \\
2 & + & 17 & + \\
3 & + & 18 & + \\
4 & + & 19 & + \\
5 & + & 20 & + \\
6 & + & 21 & + \\
7 & + & 22 & + \\
8 & + & 23 & - \\
9 & + & 24 & + \\
10 & + & 25 & + \\
11 & - & 26 & + \\
12 & + & 27 & - \\
13 & + & 28 & + \\
14 & + & 29 & + \\
15 & + & 30 & + \\
\hline
\end{tabular}

Note: $(+)=$ the results in the preparation show brown color in cell cytoplasm, $(-)=$ the results in the preparation do not show brown color in cell cytoplasm

Table 2. Percentage of cytokeratin 19 smear results in oral mucous smear preparation from subjects.

\begin{tabular}{ccc}
\hline Result preparation & Total Preparation & $\%$ \\
\hline Positive & 26 & 86.67 \\
Negative & 4 & 13.33 \\
\hline Total & 30 & 100 \\
\hline
\end{tabular}

may be caused by inflammation. The condition is influenced by many factors including bacteria, virus, parasite infections, chemical irritants and non digestible particles. If the inflammation continues than there is a risk of malignancy. ${ }^{7}$

Chronic inflammation is an immune reaction towards a persistent antigen that resulting in lymphocyte proliferation and/or plasma cell (lymphocyte B) proliferation that often without any pain, enlargement or heat. ${ }^{9}$

The epithelial structural protein is keratin and proteins related to keratin is useful for a differentiation marker. The progenitor cell is situated in the basal layer of the thin epithelial such as on the mouth base, cheek, esophagus, and palate. Many factors, including aging and diseases, can change this balance that an epithelial can undergo thickening (hyperplastic) or thinning (atrophy) compared to the normal condition.
The condition plays a role as a protective mechanism through colony and microorganism invasion limitation that may stick on the mucous surface. ${ }^{10}$

A constant stimulation from smoking habit where carcinogenic substances in the smoke and heat contained is found along with plaque deposit, calculus, staining on the teeth due to neglecting oral hygiene in the study subjects. This may become the causal factors that trigger chronic inflammation condition. This condition supports changes in epithelial cell at the basal layer of the oral cavity that may, in turn, trigger an increase in progenitor cell proliferation number.

The immunohistochemistry examination has been frequently used to detect the presence of malignancy in a tissue. Cancer or malignancy starts with a cell that is mutated. From that reality, it can be inferred that this technique can be used to detect early disorder in a cell of a tissue that looks normal from the clinical view. In this study, the author performed examination on filter cigarette smoker mucous epithelial tissue that is clinically normal but it is revealed that the tissue shows a positive reaction towards cytokeratin 19 .

\section{CONCLUSION}

Based on thestudy performed on thepresence of cytokeratin 19 in mucous swab of cigarette smoker's oral cavity using immunohistochemistry smear method, it can be concluded that $6.89 \%$ cytokeratin 19 is found in the epithelial cells as a marker of increased progenitor cells in filter cigarette smoker's oral cavity mucous. It is necessary to disseminate the danger of smoking filter cigarette for health to smokers so that they can stop their habit immediately.

\section{REFERENCES}

1. Sirait AM, Pradono YI, Toruan L. Perilaku merokok di Indonesia. Buletin Penelitian Kesehatan 2002;30(3): 139-52.

2. Ruslan G. Efek merokok terhadap rongga mulut. J PDGI 1993;42(2):22-6.

3. Uddin J. Tobacco smoking: blessing or course. J K YARSI 1995;3(2);68-94.

4. Sudhana W. Peranan kebiasaan merokok terhadap insidensi karies. J kedokteran Gigi 
Universitas Indonesia 2001:388-94.

5. Mac Gregor IDM. Effects of smoking on oral ecology. Dent Rev 1991:4-9.

6. Novocastra. Novocastra product range. North America. 2005.

7. Shacter E. Chronic inflammation and cancer. Oncology 2002:6(2).

8. Paulsen DF. Basic histology examination and board review. $2^{\text {nd }}$ ed. Appleton \& Lange; 1993.

9. Crawford WH. Acute and chronic inflammation. [cited 2007 Sept 24]. Available from:http:// www.use.edu/hsc/dental/PTHL312abc/ 312a/03/Reader/reader.pdf.

10. Chrismawaty BE. Peran struktur rongga mulut dalam mekanisme blokade fisik terhadap iritan. MIKGI 2003:244-50. 